\begin{tabular}{l|lll|}
\hline History Article & Received: Agustus 2020 & Approved: Agustus 2020 & Published: Agustus 2020 \\
\hline
\end{tabular}

\title{
PENGARUH VARIASI DOSIS BIOPESTISIDA BATANG SERAI (Andropogon nardus L.) TERHADAP PERTUMBUHAN DAN KETAHANAN SERANGAN HAMA BAYAM MERAH (Alternanthera amoena Voss)
}

\author{
Wiwit Turindah Rahayu ${ }^{1}$, Achyani $^{2}$, Hening Widowati ${ }^{3}$ \\ ${ }^{123}$ Program Pascasarjana Pendidikan Biologi, Universitas Muhammadiyah Metro \\ Email: ${ }^{1}$ wiwitturindah2@gmail.com, ${ }^{2}$ acysbd@gmail.com, ${ }^{3}$ hwummetro@gmail.com
}

\begin{abstract}
Abstrak : Tujuan dari penelitian ini adalah untuk mengetahui pengaruh pemberian variasi dosis batang serai terhadap pertumbuhan dan ketahanan serangan hama bayam merah. Penelitian ini juga diharapkan menjadi sumber belajar biologi. Desain penelitian yang digunakan adalah Rancangan Acak Lengkap (RAL) dengan satu control dan 3 perlakuan. P1: batang serai dengan dosis $35 \%$, P2: batang serai dengan dosis $40 \%$, dan P3: batang serai dengan dosis 45\%, dengan tiap perlakuan 6 kali pengulangan. Pertumbuhan dan ketahanan hama bayam merah dianalisis mengganakan ANAVA 1 jalur. Hasil menunjukkan ada pengaruh variasi penggunaan dosis batang serai karena hasil $\mathrm{F}$ hitung lebih besar dari F table pada table C square. Dosis $45 \%$ batang serai menghasilkan pengaruh terbaik pada pertumbuhan dan ketahanan hama bayam merah. Penelitian ini juga memiliki potensi sebagai sumber belajar biologi menggunakan pendekatan ilmiah.
\end{abstract}

Kata Kunci: biopestisida batang serai, pertumbuhan dan ketahanan serangan hama, potensi sumber belajar

\begin{abstract}
The purpose of this study was to determine the effect of variations in the dosage of lemongrass biopesticides and the best dose on the growth and resistance of red spinach pests. This research is also expected to be a potential source of learning biology. The research design used was a Completely Randomized Design (CRD) with one control and 3 treatments, P1: citronella stem biopesticide dose 35\% P2: citronella stem biopesticide dose 40\%, and P3: citronella stem biopesticide dose 45\%, with each treatment using 6 replications. Growth and resistance of red spinach pests were analyzed using 1-way ANAVA. The results showed there was an effect of variations in the dosage of lemongrass biopesticide on growth and resistance of red spinach pests because the Fcount value was greater than the Ftable in the Chi-square table. $45 \%$ dosage of lemongrass biopesticide has the best influence on the growth and resistance of red spinach pests. This research also has the potential as a source of learning biology by using a scientific approach.
\end{abstract}

Keywords: lemongrass biopesticides, Growth and resistance of red spinach pests, potential as source of learning

\section{How to Cite}

Rahayu, Wiwit Turindah, Achyani, \& Hening Widowati. 2020. Pengaruh Variasi Dosis Biopestisida Batang Serai (Andropogon nardus L.) terhadap pertumbuhan dan ketahanan Serangan Hama Bayam Merah (Alternanthera amoena Voss). Biolova 1(2). 68-77. 
Bayam merah (Alternanthera amoena Voss) merupakan salah satu jenis tanaman hortikultura introduksi yang mulai dikembangkan di Indonesia beberapa tahun terakhir.Jenis sayuran ini lebih unggul dibandingkan dengan jenis bayam lainnya karena tinggi nilai ekonomis dan gizi, serta warnanya yang lebih menarik. Selain banyak mengandung protein, vitamin $\mathrm{A}$, vitamin $\mathrm{C}$, dan garam-garam mineral yang sangat dibutuhkan oleh tubuh, bayam merah juga mengandung antosianin sebagai antioksidan serta dapat dimanfaatkan dalam menyembuhkan penyakit anemia (Tapilouw dalam Bria, 2016).Bayam merah semula dikenal sebagai tanaman hias, namun dalam perkembangan selanjutnya bayam merah difungsikan sebagai bahan pangan sumber protein, vitamin A dan $\mathrm{C}$ sedikit vitamin $\mathrm{B}$, mengandung garam-garam mineral dan pigmen antosianin. Antosianin termasuk senyawa fenolik yang masuk kelompok flavonoid dan berfungsi sebagai antioksidan.Bayam merah termasuk tanaman yang mudah terserang hama, sehingga petani masih menggunakan pestisida sistesis untuk hasil yang baik.Berdasarkan pernyataan Subandi (2015), hama yang banyak menyerang tanaman bayam adalah ulat grayak dan belalang. Kedua hama tersebut menyerang bayam merah dan menyebabkan kerusakan pada daun. Hama lain yang juga sering ditemukan pada tanaman bayam merah adalah kutu daun dan juga siput. Kutu daun bekerja menyerang bagian daun dan menyebabkan kerusakan pada daun, dan jika sudah parah akan menyebabkan daun rontok. Siput menyerang bayam merah pada saat bayam masih dalam tahap penyemaian, yaitu menyerang dengan cara memakan bagian daun bayam hingga habis.Perkembangan hama sangat dipengaruhi oleh dinamika faktor iklim. Hama seperti mahluk hidup lainnya, perkembangan hidupnya dipengaruhi oleh faktorfaktor seperti suhu, kelembaban udara, curah hujan dan lain sebagainya.Faktor iklim tersebut berpengaruh terhadap banyak hal seperti siklus hidup, keperidian atau kemampuan untuk menghasilkan keturunan, lama hidup dan sebagainya.

Penggunaan pestisida sintetis yang berlebihan memberi dampak negatif terhadap lingkungan dan manusia. Keseimbangan alam terganggu dan akan mengakibatkan timbulnya hama yang resisten. Salah satu penyebab terjadinya dampak negatif pestisida terhadap lingkungan adalah adanya residu pestisida di dalam tanah sehingga dapat meracuni organisme lainnya.Bahkan, residu pestisida pada tanaman dapat terbawa sampai pada rantai makanan sehingga dapan meracuni konsumen baik hewan maupun manusia.Hal tersebut membuat para petani mulai beralih untuk mengembangkan pertanian organik yang dimulai dengan penggunaan pupuk organik.Pupuk organik cair merupakan pupuk yang dibuat dari hasil pembusukan bahanbahan organik yang berasal dari sisa tanaman, kotoran hewan, dan manusia. Pupuk organik cair mengandung unsur hara yang dapat memenuhi kebutuhan tanaman dan tidak akan merusak lingkungan. Salah satu pupuk organik cair yang dapat digunakan untuk tumbuhan adalah pupuk Limbah Cair Nanas (LCN) yang berasal dari sisa pengolahan buah nanas.Kandungan pupuk Limbah Cair Nanas (LCN) dapat memenuhi kabutuhan dari unsur hara tanaman. Unsur hara yang dibutuhkan oleh tanaman itu dapat berupa unsur hara makro dan unsur hara mikro di antaranya adalah $\mathrm{C}, \mathrm{N}$, $\mathrm{P}, \mathrm{K}, \mathrm{Ca}, \mathrm{Mg}, \mathrm{Na}, \mathrm{Fe}, \mathrm{Zn}, \mathrm{Mn}, \mathrm{S}, \mathrm{NO}_{3}$, $\mathrm{NH}_{4}$, dan $\mathrm{C} / \mathrm{N}$ (Julius dalam Sutanto 
,2011). Limbah Cair Nanas (LCN) dengan semua kandungan haranya dapat dijadikan sebagai pupuk organik bagi tanaman bayam merah. Selain pupuk, unsur penting dalam merawat tanaman sayuran dibutuhkan pestisida yang dapat mencegah hama agar tidak merusak tanaman. Hama yang datang dapat menyerang tanaman bayam merah seperti ulat dan wereng yang bisa berakibat pada kerusakan tanaman, seperti daun berlubang dan juga kering.Hal tersebut membuat para petani rugi, sehingga mengambil langkah untuk menggunakan pestisida kimia karena dinilai lebih praktis dan efektif membasmi hama.

Pembuatan pertanian organik harus sesuai dengan aturan-aturan tertentu termasuk harus menggunakan pestisida yang berbahan alami agar tidak merusak lingkungan.Salah satu unsur penting dalam sistem pertanian organik adalah penggunaan pestisida alami atau biopestisida. Penggunaan biopestisida yang bersifat alami akan lebih aman dan tidak membahayakan lingkungan serta makhluk hidup yang ada di sekitar. Pembuatan biopestisida dapat berasal dari tanaman yang mengandung zat racun seperti minyak atsiri pada tanaman serai yang bersifat repellent terhadap hama.Berdasarkan pernyataan dari Kardinan (2003:21) bahwa tanaman serai banyak mengandung minyak atsiri, yang terdiri dari senyawa sitral, sitronela, geraniol, mirsena, nerol, farnesol, metil heptenon dan dipentena. Kandungan senyawa-senyawa tersebut yang menjadikan tanaman Serai mempunyai sifat yang toksik terhadap hama, sehingga dapat digunakan untuk pengendalian organisme pengganggu tanaman.Interaksi yang terjadi antara biopestisida, hama, dan lingkungan yang ada, dapat berpotensi sebagai sumber belajar biologi yang berbasis lingkungan.
Sumber belajar

dapat dirumuskan sebagai sesuatu yang dapat memberikan kemudahan kepada peserta didik dalam memperoleh sejumlah informasi, pengetahuan, pengalaman dan keterampilan dalam proses belajar dan pembelajaran.Sumber belajar berkaitan dengan segala sesuatu yang memungkinkan siswa dapat memperoleh pengalaman belajar, di dalamnya meliputi lingkungan fisik seperti tempat belajar, bahan dan alat yang digunakan, personal seperti guru, petugas perpustakaan, dan siapa saja yang berpengaruh baik langsung maupun tidak langsung untuk keberhasilan dalam pengalaman belajar(Sanjaya, 2011:12)

Lingkungan merupakan sumber belajar yang unik dan menarik untuk siswa, dimana terjadi interaksi langsung antara pembelajar dengan sumber belajar.Lingkungan yang berpotensi sebagai sumber belajar diantaranya adalah lingkungan sosial, lingkungan alam, dan lingkungan buatan.Ketiga lingkungan tersebut dapat berpotensi sebagai sumber belajar biologi yang baik.Dengan memanfaatkan lingkungan sebagai sumber belajar, peran guru sebagai fasilitator dalam pelaksanaan pembelajaran harus mampu memberikan kemudahan kepada siswa untuk dapat mempelajari berbagai hal yang terdapat di lingkungan. Menurut (Munajah, 2015) Faktor yang menyebabkan rendahnya kualitas pembelajaran antara lain belum dimanfaatkan sumber belajar secara maksimal, baik guru maupun oleh peserta didik. Sistem pembelajaran pada kurikulum 2013 lebih menekankan pada pengalaman lapangan untuk proses pembelajaran, meningkatkan pengetahuan, pemahaman dalam ruang lingkup sumber belajar. Kurikulum 2013 diharapkan mampu meningkatkan 
kreatifitas dan kemampuan guru untuk menggali potensi lokal untuk dijadikan sumber belajar. Lingkungan dapat memberikan pengalaman belajar yang tidak ditemukan oleh siswa saat pembelajaran di dalam kelas. Pemanfaatan potensi lokal yang ada di daerah sekitar, dapat dijadikan salah satu alternatif sumber belajar yang menarik. Salah satunya adalah agrowisata sayur organik sebagai tempat penelitian.

\section{METODE}

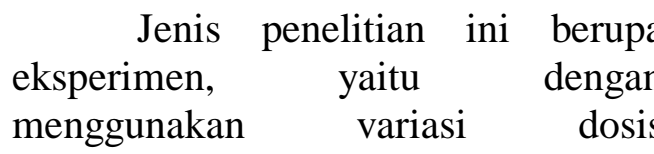
biopestisida batang serai yang akan digunakan untuk mengetehui pengaruhnya terhadap pertumbuhan dan ketahanan serangan hama pada tanaman bayam merah. Penelitian ini akan menggunakan rancangan acak kelompok (RAK) karena dilakukan dalam kondisi lingkungan, alat, bahan, dan media yang tidak homogen. Penelitian ini dilakukan dengan 4 perlakuan dengan 6 kali pengulangan yaitu dengan memberikan biopestisida batang serai dengan masing-masing dosis pada tanaman bayam merah. Bayam merah yang digunakan sebanyak 5 batang pada setiap sampel dengan dosis yang digunakan adalah $35 \%, 40 \%, 45 \%$. Desain rancangan penelitian ini dapat dilihat pada Tabel 1.

Tabel 1. Rancangan Penelitian

\begin{tabular}{|c|c|c|c|c|c|c|}
\hline Ulangan & $\mathbf{U}$ & $\mathbf{U}$ & $\mathbf{U}$ & $\mathbf{U}$ & $\mathbf{U}$ & $\mathbf{U}$ \\
\hline $\begin{array}{l}\text { Perlakua } \\
\text { n }\end{array}$ & 1 & 2 & 3 & 4 & 5 & 6 \\
\hline $\mathbf{P}$ & 5 & 5 & 5 & 5 & 5 & 5 \\
\hline $\mathbf{P}_{2}$ & 5 & 5 & 5 & 5 & 5 & 5 \\
\hline $\mathbf{P}_{3}$ & 5 & 5 & 5 & 5 & 5 & 5 \\
\hline $\mathbf{P}_{4}$ & 5 & 5 & 5 & 5 & 5 & 5 \\
\hline
\end{tabular}

Keterangan:

$\mathrm{K}$ : kontrol (tidak diberi perlakuan)

A : Perlakuan dengan dosis $35 \%$

B : Perlakuan dengan dosis $40 \%$

C : Perlakuan dengan dosis $45 \%$

U1 : Ulangan kesatu

U2 : Ulangan kedua

U3 : Ulangan ketiga

U4 : Ulangan keempat

U5: Ulangan kelima

U6: Ulangan keenam

\section{HASIL}

Berdasarkan penelitian yang telah dilakukan dengan menggunakan 3 variasi dosis biopestisida batang serai yang berbeda yaitu perlakuan ke1 menggunakan dosis 35\% biopestisida batang serai, perlakuan ke-2 menggunakan $40 \%$ larutan batang serai, perlakuan ke--3 menggunakan $45 \%$ larutan batang serai, serta kontrol yang tidak diberikan larutan batang serai. Masing-masing perlakuan menggunakan 6 kali ulangan yang menghasilkan rata-rata pertumbuhan dan ketahanan serangan hama bayam merah yang berbeda-beda. Data pertama yang diperoleh adalah hasil pengamatan mengenai berat basah bayam merah dengan menggunakan variasi dosis biopestisida batang serai dengan rata-rata yang dapat dilihat pada Gambar 1.

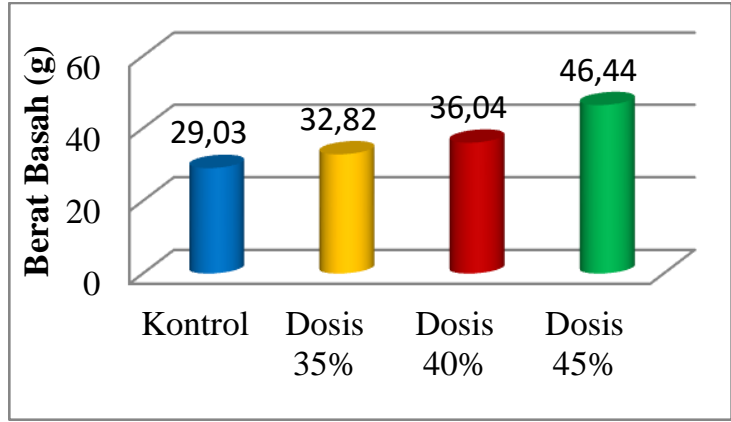

Gambar 1. Rata-rata Berat Basah Bayam Merah (g) 
Berdasarkan diagram pada Gambar 1 dapat diketahui bahwa bayam merah pada setiap perlakuan menghasikan berat basah yang berbeda-beda dan selalu mengalami peningkatan. Dosis yang pertama yaitu $35 \%$ biopestisida batang serai dengan 6 kali ulangan yang menghasilkan rata-rata berat basah yaitu 32,82 gram. Dosis yang kedua yaitu dosis $40 \%$ biopestisida batang serai yang mengalami peningkatan rata-rata berat basah dari 6 kali ulangan yaitu 36,04 gram, dan pada dosis yang ketiga yaitu dosis 45\% dengan 6 kali ulangan yang mengalami peningkatan rata-rata berat basah bayam merah yang paling tinggi yaitu 46,44 gram. Berat basah terendah yakni pada kontrol dengan rata-rata berat basah dari 6 kali ulangan yaitu 29,03 gram. Kontrol tidak diberikan perlakuan seperti pada dosis lainnya sehingga berat basah bayam merah menjadi rendah dibandingan dengan perlakuan menggunakan biopestisida batang serai.

Data hasil pengamatan yang diukur selanjutnya adalah ketahanan serangan hama bayam merah yang diambil melalui 3 parameter yaitu jumlah individu yang terserang hama, jumlah lubang pada bayam merah yang terserang hama, dan luas lubang pada daun bayam merah yang terserang hama. Rata-rata jumlah individu bayam merah yang terserang hama pada setiap perlakuan dapat dilihat pada Gambar 2.

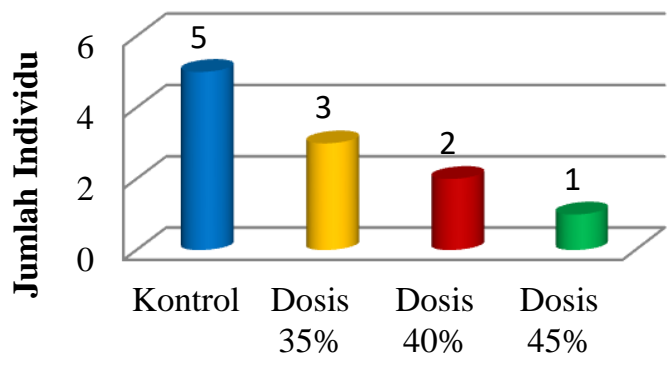

Gambar 2.Rata-rata Jumlah Individu yang Terserang
Berdasarkan diagram pada Gambar 2 dapat diketahui bahwa jumlah individu bayam merah pada setiap perlakuan mempunyai jumlah yang berbeda-beda pada setiap perlakuan yang diberikan. Dosis yang pertama yaitu $35 \%$ biopestisida batang serai dengan 6 kali ulangan yang menghasilkan rata-rata jumlah individu bayam merah yang terserang hama yaitu 3 batang. Dosis yang kedua yaitu dosis $40 \%$ biopestisida batang serai yang mengalami penurunan rata-rata jumlah individu yang terserang hama dari 6 kali ulangan yaitu 2,3 batang yang terserang, dan pada dosis yang ketiga yaitu dosis $45 \%$ dengan 6 kali ulangan dengan rata-rata jumlah individu bayam merah yang terserang hama paling rendah yaitu hanya 1 batang. Tingkat serangan hama paling tinggi yaitu pada kontrol dengan rata-rata jumlah individu bayam merah yang terserang hama dari 6 kali ulangan yaitu 5 batang yang artinya semua bayam merah terserang hama.

Parameter selanjutnya yang diamati adalah jumlah lubang pada bayam merah pada setiap perlakuan.Rata-rata hasil jumlah lubang pada bayam merah dapat dilihat padaGambar 3.

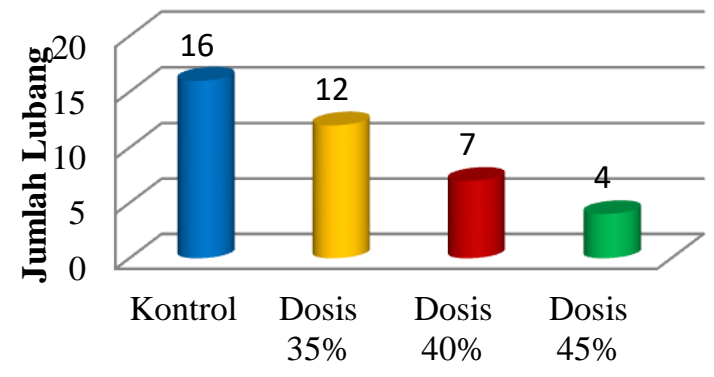

Gambar 3.Rata-rata Jumlah Lubang pada Tanaman Bayam Merah

Berdasarkan diagram pada Gambar 3 dapat diketahui rata-rata jumlah lubang bayam merah pada 
setiap perlakuan mempunyai jumlah yang berbeda-beda pada setiap perlakuan yang diberikan. Dosis yang pertama yaitu $35 \%$ biopestisida batang serai dengan 6 kali ulangan yang menghasilkan rata-rata jumlah lubang pada daun bayam merah yang terserang hama yaitu 12 lubang. Dosis yang kedua yaitu dosis $40 \%$ biopestisida batang serai yang mengalami penurunan rata-rata jumlah lubang pada daun bayam merah yang terserang hama dari 6 kali ulangan yaitu berjumlah 7 lubang. Dosis yang ketiga yaitu dosis $45 \%$ dengan 6 kali ulangan dengan rata-rata jumlah lubang pada daun bayam merah yang terserang hama yaitu berjumlah 4 lubang. Jumlah lubang yang terdapat pada daun bayam merah yang paling tinggi yaitu pada kontrol dengan ratarata jumlah lubang pada daun bayam merah yaitu 16 lubang dari 6 kali ulangan. Kontrol tidak diberikan perlakuan seperti pada dosis lainnya sehingga jumlah lubang pada daun bayam merah yang terserang hama menjadi lebih tinggi dibandingan dengan yang diberikan perlakuan menggunakan biopestisida batang serai.

Parameter ketahanan serangan hama bayam merah yang ketiga yaitu luas lubang yang terdapat pada daun bayam merah. Rata-rata data hasil penelitian mengenai luas lubang pada daun bayam merah dapat dilihat pada Gambar 4.

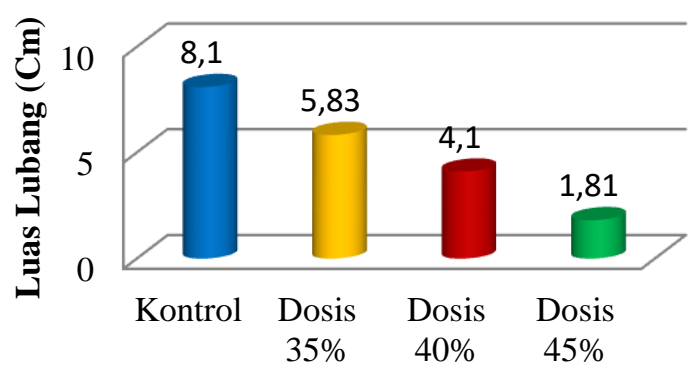

Gambar 4.Rata-rata Luas Lubang pada Daun Bayam Merah (Cm)
Berdasarkan diagram pada Gambar 4 dapat diketahui bahwa luas lubang bayam merah pada setiap perlakuan mempunyai rata-rata yang berbeda-beda pada setiap perlakuan yang diberikan. Dosis yang pertama yaitu $35 \%$ biopestisida batang serai dengan 6 kali ulangan yang menghasilkan rata-rata luas lubang pada daun bayam merah yang terserang hama yaitu $5,83 \mathrm{~cm}$. Dosis yang kedua yaitu dosis $40 \%$ biopestisida batang serai yang mengalami penurunan rata-rata luas lubang pada daun bayam merah yang terserang hama dari 6 kali ulangan yaitu dengan luas $4,1 \mathrm{~cm}$. Dosis yang ketiga yaitu dosis $45 \%$ dengan 6 kali ulangan dengan rata-rata luas lubang pada daun bayam merah yang terserang hama yaitu $1,81 \mathrm{~cm}$. Luas lubang pada daun bayam merah yang paling tinggi yaitu pada kontrol dengan rata-rata luas lubang dari 6 kali ulangan adalah 8,61 cm. Kontrol tidak diberikan perlakuan seperti pada dosis lainnya sehingga luas lubang yang terdapat pada daun bayam merah yang terserang hama menjadi lebih tinggi dibandingan dengan yang diberikan perlakuan menggunakan biopestisida batang serai. Hasil dari rata-rata pertumbuhan dan ketahanan serangan hama bayam merah menunjukkan bahwa semakin rendah serangan hama pada bayam merah, maka berat basah bayam merah akan semakin tinggi.

\section{PEMBAHASAN \\ Pengaruh Variasi Dosis Biopestisida Batang Serai terhadap Berat Basah Tanaman Bayam Merah}

Pertumbuhan bayam merah yang mempunyai berat basah berbedabeda disebabkan oleh adanya perbedaan dosis biopestisida batang serai yang diberikan. Hal ini menunjukkan bahwa perbedaan variasi 
dosis biopestida batang serai berpengaruh terhadap berat basah bayam merah. Bayam merah yang tidak diberikan biopestida batang serai mempunyai berat basah yang rendah dikarenakan pertumbuhan bayam merah akan terganggu oleh hama yang menyerang. Organisme pengganggu tanaman merupakan faktor pembatas produksi tanaman di Indonesia baik tanaman pangan, hortikultura, maupun perkebunan (Wahyono,2012). Faktor tersebut yang menyebabkan berat basah yang dihasilkan dari bayam merah yang tidak diberi biopestida batang serai akan rendah karena hama akan terus menyerang tanaman. Efek yang ditimbulkan dari aktivitas berbagai macam hama berbeda-beda, mulai dari merusak bagian daun, batang, hingga seluruh bagian tanaman bayam merah. Hama mulai menyerang bayam merah bahkan dimulai saat pada proses penyemaian, sehingga tanaman yang tidak diberikan biopestida batang serai akan sangat terganggu pertumbuhann dan menghasilkan berat basah yang rendah. Berat basah bayam merah pada dosis $45 \%$ menghasilkan ratarata yang paling tinggi, hal ini dikarenakan tanaman dapat tumbuh dengan baik tanpa adanya gangguan hama.

Pemberian biopestisida batang serai sangat berpengaruh terhadap berat basah bayam merah karena kondisi pertumbuhan bayam merah akan baik tanpa gangguan serangga. Hal tersebut menjadikan biopestisida batang serai sebagai sistem perlindungan dari luar agar bayam merah dapat tumbuh dengan baik. Berat basah bayam merah akan tinggi apabila kondisi bayam merah mempunyai batang yang segar, daun yang tidak rontok, dan juga daun yang tidak berlubang.Faktor lain yang dapat mempengaruhi pertumbuhan bayam merah adalah nutrisi. Nutrisi yang dibutuhkan untuk pertumbuhan bayam merah berupa unsur hara makro dan unsur hara mikro yang didapatkan dari pupuk Limbah Cair Nanas. Limbah Cair Nanas mengandung unsur hara yang dibutuhkan oleh tanaman mulai dari unsur hara makro dan unsur hara mikro diantaranya adalah $\mathrm{C}, \mathrm{N}, \mathrm{P}, \mathrm{K}$, $\mathrm{Ca}, \mathrm{Mg}, \mathrm{Na}, \mathrm{Fe}, \mathrm{Zn}, \mathrm{Mn}, \mathrm{S}$, NO3, NH4, dan C/N (Sutanto, 2015:2). Unsur hara tersebut sangat memenuhi kebutuhan nutrisi tumbuhan sehingga dapat dijadikan sebagai pupuk organik yang akan menutrisi dari dalam.

Biopestisida batang serai dan pupuk Limbah Cair Nanas sangat berhubungan dengan berat basah bayam merah. Keduanya memberikan peran masing-masing dalam proses pertumbuhan bayam merah. Biopestisida batang serai sebagai faktor eksternal yang dapat meningkatkan berat basah bayam merah dengan cara melindungi tanaman dari serangan hama dan pupuk Limbah Cair Nanas sebagai faktor internal yang akan memenuhi kebutuhan unsur hara tanaman bayam merah. Hal tersebut dapat dilihat dari tanaman bayam merah yang tidak diberi biopestisida batang serai atau yang diberi dengan dosis $35 \%$ dan $40 \%$, maka proses pertumbuhannya akan terganggu walaupun nutrisi yang didapatkan sudah cukup. Ini menunjukkan bahwa antara faktor eksternal dengan faktor internal harus seimbang agar pertumbuhan bayam merah bisa menghasilkan berat basah yang tinggi.

Pengaruh Variasi Dosis Biopestisida Batang Serai terhadap Ketahanan Serangan Hama pada Bayam Merah

Parameter pertama yang dihitung pada ketahanan serangan hama bayam merah adalah jumlah individu yang terserang dari masingmasing dosis yang diberikan. Hasil yang didapat dari dosis $35 \%$ rata-rata 
bayam merah yang terserang hama ada 4 batang dari 5 batang sampel yang digunakan. Hal tersebut menunjukkan bahwa tingkat serangan hama sangat tinggi pada dosis 35\%. Biopestisida batang serai dengan dosis $35 \%$ masih dapat ditoleransi oleh hama karena hama di lingkungan agrowisata Karang Rejo sudah resisten terhadap berbagai pestisida. Hal ini disebabkan karena hama biasa dikendalikan menggunakan pestisida sistetis dengan dosis yang tingggi agar dapat mati. Tingkat serangan hama dapat dipengaruhi oleh beberapa faktor salah satunya adalah faktor cuaca. Hama dapat menyerang kapan saja sesuai waktu pertumbuhan tanaman. Hama ulat banyak menyerang pada waktu musim kemarau. Perkembangan populasi ulat grayak (Spodoptera exigua $\mathrm{Hbn}$ ) lebih tinggi pada musim kemarau dari pada musim hujan, karena pada curah hujan yang tinggi menyebabkan menurunnya populasi ulat grayak (Spodoptera exiguaHbn) akibat tercuci oleh hujan serta aktivitas hama ini akan menurun ketika hujan turun (Astuti, 2018). Biopestisida berperan penting dalam proses pengendalian hama, karena jika tidak diberi biopestida maka akan semakin banyak bayam merah yang terserang. Bayam merah yang diberi dosis $45 \%$ biopestisida batang serai mampu bertahan dari serangan hama ulat karena dari 5 sampel rata-rata hanya satu tanaman yang terserang.

Parameter kedua dan ketiga dalam mengukur ketahanan serangan hama yaitu dengan menghitung jumlah lubang dan juga luas lubang yang terdapat pada daun bayam merah. Hama yang meyerang bayam merah biasanya menyerang daun mulai dari proses penyemaian hingga bayam tumbuh. Ulat atau hama lainnya mampu memakan daun hingga menghabiskan satu bagian daun, hal tersebut tentu saja akan menjadikan daun bayam merah rontok. hama yang banyak menyerang tanaman bayam adalah ulat grayak dan belalang. Kedua hama tersebut menyerang bayam merah dan menyebabkan kerusakan pada daun. Hama lain yang juga sering ditemukan pada tanaman bayam merah adalah wereng dan juga siput. Wereng bekerja menyerang bagian daun dan menyebabkan kerusakan pada daun, dan jika sudah parah akan menyebabkan daun rontok. Siput menyerang bayam merah pada saat bayam masih dalam tahap penyemaian, yaitu menyerang dengan cara memakan bagian daun bayam hingga habis.Hama yang menyerang tanaman bayam antara lain ulat grayak (Spodoptera litura), dan belalang (Locusta nigratoria). Kedua hama tersebut menyerang dan merusak tanaman pada bagian daun.

Tanaman bayam merah yang diberikan biopestisida batang serai $45 \%$ terdapat kerusakan daun yang tidak banyak, hal ini dikarenakan kandungan minyak atsiri pada batang serai yang mempunyai daya tolak terhadap hama. Kandungan biopestisida batang serai diantaranya adalah minyak atsiri, yang terdiri dari senyawa sitral, sitronela, geraniol, mirsena, nerol, farnesol, metil heptenon dan dipentena. Kandungan senyawa-senyawa tersebut yang menjadikan tanaman serai mempunyai sifat yang toksik terhadap hama, sehingga dapat digunakan untuk pengendalian organisme pengganggu tanaman. Efek dari senyawa ini bagi perkembangan hidup serangga dapat menghambat dalam peletakan telur sehingga secara tidak langsung dapat memperlambat perkembangbiakan hama. Biopestisida batang serai merupakan racun perut yang dapat menyebabkan hama mati, karena pada saat biopestisida batang serai disemprotkan pada bayam merah maka hama akan memakan daun 
bayam merah yang tercampur dengan larutan biopestisida batang serai, sehingga akan masuk dalam sistem percernaan. Sistem pencernaan hama yang akan terganggu yaitu pada bagian usus penyerapan, karena pada bagian ini senyawa sitronela akan menyerap air secara berlebih sehingga akan menyebabkan hama mengalami dehidrasi dan penurunan nafsu makan. Biopestisida dapat membunuh dan mengganggu serangan hama dan penyakit melalui cara kerjanya yang unik yaitu dengan (1) merusak perkembangan telur, larva dan pupa (2) menghambat pergantian kulit (3) mengganggu komunikasi serangga (4) menyebabkan serangga menolak makanan (5) menghambat reproduksi serangga betina (6) mengurangi nafsu makan (7) memblokir kemampuan makan serangga (8) mengusir serangga (9) menghambat perkembangan petogen penyakit (Sudarmo,2006:16). Cara kerja biopestisda batang serai mampu meningkatkan ketahanan serangan hama bayam merah dengan cara mengganggu sistem pecernaan hama. Hal tersebut dapat dilihat dari jumlah lubang dan juga luas lubang pada daun bayam merah yang semakin menurun jika diberikan dosis 45\%, yang membuktikan bahwa variasi dosis biopestisida batang serai berpengaruh terhadap ketahanan serangan hama pada bayam merah.

\section{Analisis Potensi Penelitian sebagai Sumber Belajar Biologi}

Berdasarkan penelitian yang telah dilakukan diperoleh konsep, fakta, data, dan prinsip yang kemudian dianalisis potensi berdasarkan pada kompetensi dasar, karakterisitik materi, kondisi lingkungan dan tujuan pembelajaran. Analisis potensi yang disusun berdasarkan dengan kurikulum yang berlaku dan juga menekankan pada pendekatan saintifik. Menurut pendapat Surasmi (2017) menyatakan bahwa pembelajaran dengan pendekatan saintifik adalah proses pembelajaran yang dirancang agar peserta didik secara aktif mengonstruk konsep, hukum atau prinsip melalui tahapantahapan mengamati (mengidektifiksi atau menemukan masalah), merumuskan masalah, merumuskan hipotesis, mengumpulkan data dengan berbagai teknik, mengalisis data, menarik kesimpulan dan mengkomunikasikan konsep, hukum, atau prinsip yang ditemukan. Sumber belajar biologi dapat ditemukan dari mana saja termasuk dari lingkungan sekitar. Proses pembelajaran berdasarkan pendekatan saintifik sangat menekankan siswa untuk bersikap mandiri dan juga peka terhadap permasalahan lingkungan sekitar sehingga penelitian ini berpotensi sebagai sumber belajar biologi SMA untuk kelas X, kelas XI, dan kelas XII.

\section{KESIMPULAN}

Berdasarkan hasil penelitian yang telah dilakukan, dapat disimpulkan bahwa: 1) Ada pengaruh biopestisida batang serai terhadap pertumbuhan dan ketahanan serangan hama pada tanaman bayam merah; 2) Dosis $45 \%$ yang memberikan pengaruh paling baik dan efektif terhadap pertumbuhan dan ketahanan serang hama bayam merah. 3) Penelitian ini berpotensi sebagai sumber belajar biologi SMA dengan pendekatan saintifik.

\section{DAFTAR RUJUKAN}

Astuti, Tina. 2018. Pemberian Bioinsektisida terhadap Perkembangan Populasi dan Intensitas Hama Ulat Grayak (Spodoptera exigua $\mathrm{Hbn}$ ) pada 
Tanaman Bawang Merah (Allium ascalonicum L.).Skripsi Tidak Diterbitkan. Nusa Tenggara Barat: Universitas Mataram.

Bria, Deseriana. 2016. Pengaruh Jenis dan Konsentrasi Teh Kompos terhadap Pertumbuhan dan Hasil Bayam Merah (Alternanthera amoena Voss).Junal Pertanian Konservasi Lahan Kering ISSN 2477-7927.

Kardinan, Agus. 2004. Pestisida Nabati Ramuan danAplikasi. Jakarta: PT. Penebar Swadaya.

Munajah dan Muhammad Joko Susilo.2015. Potensi Sumber Belajar Biologi SMA Kelas X Materi Keanekaragaman Tumbuhan Tingkat Tinggi di Kebun Binatang Gembira Loka.Jupemasi-Pbio Vol. 1 No. 2. ISSN 2407-1269 : 184-187.

Sanjaya, Wina. 2011. Perencanaan Dan Desain Sistem Pembelajaran. Bandung: Kencana Prenadamedia Grup.

Sudarmo.2006. Pestisida Nabati Pembuatan dan Pemanfaatannya. Yogyakarta: KANISIUS.

Surasmi, Wuwuh Asrining. 2017. Penerapan Pendekatan Saintifik dalam proses Pembelajaran Kurikulum 2013. Skripsi tidak diterbitkan. Surabaya: Universitas Terbuka UPBJJ.

Sutanto, Agus. 2010. Bioremediasi Limbah Cair Nanas. Malang: Universitas Muhammadiyah Malang.
Sutanto, Agus dan Arifah Qurniani. 2015. Variasi Dosis Pupuk Cair LCN (Limbah Cair Nanas) terhadap Pertumbuhan Anggrek Dendrobium Sp untuk Menyusun Panduan Praktikum. Jurnal Bioedukatika. Vol. 3 No 1.ISSN 2338-6630.

Wahyono, Teguh dan Subanar. 2012. Rancangan Bangun Sistem "Permadi": Peringatan Dini Serangan Hama Tanaman Padi Berbasis Data Historis Klimatologi. Jurnal Sistem Komputer. Vol 2 No. 1 IISN 2087-4685. 